\title{
Influences of species mixture on biomass of Masson pine (Pinus massoniana Lamb) forests
}

\author{
L.F. Zhang ${ }^{1}$, Y.Y. Huang ${ }^{1}$, L.P. Liu ${ }^{2,3}$ and S.L. Fu ${ }^{1}$ \\ ${ }^{1}$ College of Forestry and Landscape Architecture, Anhui Agricultural University, \\ Hefei, Anhui, China \\ ${ }^{2}$ School of Natural Sciences, Anhui Agricultural University, \\ Hefei, Anhui, China \\ ${ }^{3}$ Department of Mathematical Sciences, Lakehead University, \\ Thunder Bay, Ontario, Canada \\ Corresponding author: S.L. Fu \\ E-mail: fusongling@ahau.edu.cn
}

Genet. Mol. Res. 12 (3): 3742-3749 (2013)

Received January 25, 2013

Accepted August 20, 2013

Published September 19, 2013

DOI http://dx.doi.org/10.4238/2013.September.19.5

\begin{abstract}
The effect of tree diversity on productivity in subtropical forests in China is poorly understood. We investigated the biomasses of trees, understory vegetation, coarse roots, and fine roots with varying proportions of Pinus massoniana, mixed with other tree species in stands of the same age, to examine the effects of tree diversity. With an increase of $P$. massoniana proportion, the tree and understory biomasses increased at first, and then gradually decreased. As expected, the biomass of fine roots decreased with soil depth. Stands with 40 to $60 \%$ P. massoniana had the highest biomass, whereas stands with $<20 \%$ P. massoniana had the least biomass. Stands with $<20 \%$ P. massoniana had the least understory biomass, whereas those with 20 to $40 \%$ Masson pine had the least fine root biomass.
\end{abstract}

Key words: Pinus massoniana; Mixed forest; Biomass; Undergrowth; Arboreal stratum 


\section{INTRODUCTION}

The diversity-productivity relationship of trees has received considerable attention during the past two decades, largely because a long-term pure stand production system is not sustainable owing to the decline in soil fertility and productivity (Hooper et al., 2005). Numerous empirical experiments have shown that diversity, which is also defined as the biodiversity effect, has positive relationships with productivity, meaning that polycultures have higher production biomass than the average production of monocultures (Tilman et al., 1996; Loreau et al., 2001; Cardinale et al., 2007; Isbell et al., 2009). Polycultures have the advantages of species complementation, an improved ecosystem, and higher productivity. It is well known that a good mixed plantation can improve environmental conditions, increase the stability of a forest, and maintain high productivity. These benefits accrue because coexisting species occupy different ecological niches, resulting in more complete resource usage (Tilman et al., 1996; Loreau et al, 2001; Spehn et al., 2005; Marquard et al., 2009). The Niche Complementarity Hypothesis, the cornerstone of diversity-productivity relationship studies, explains that the biodiversity effect is due to increased resource use and nutrient retention via niche differentiation or partitioning and interspecies facilitation (Tilman, 1999; Loreau et al., 2001; Hooper et al., 2005). However, it is rare, when considering the influences of species mixture on biomass changes, to directly demonstrate the link between the mixed ratio effect and biomass and productivity.

The factors discussed above can assist in identifying target species capable of inhabiting vacant forest niches, so that tree productivity would be maintained. This will also help maintain the tree composition of the forest during stand development (Pande, 2005). Studies have shown that understory vegetation refers to all plants, including shrubs, herbs, and vines, growing under the forest canopy. This understory vegetation is an important component of the forest ecosystem, playing a crucial role in improving the soil, preventing water and soil losses, and maintaining diversity and material recycling. Understory vegetation is also an important component of the forest carbon mass. Fine root biomass is closely related to the species and ages of trees in a stand. A mixed woodlot generally has a higher standing biomass than a pure stand. The biomass of fine roots $\left(<2\right.$ to $5 \mathrm{~mm}$ in diameter) varies between 46 and $2805 \mathrm{~g} / \mathrm{m}^{2}$. The fine root biomass in a forest ecosystem depends on the tree species, weather, site type, soil, community structure, and tree age. Fine roots are the important dynamic component of nutrients, playing an essential role in energy flow and material cycling in a forest ecosystem (Usman et al., 2000). In many stands, over $50 \%$ of the primary production is used in fine root maintenance (Fogel and Hunt, 1979; Grier et al., 1981; Jackson et al., 1997). Through their circulation within the fine roots, soil carbon and nutrient return may equal, and even exceed, that of the above-ground litter (Arthur and Fahey, 1992; Pregitzer et al., 1993). If the production of root biomass, especially the fine root biomass, is neglected, then the organic and nutrient turnovers will be underestimated by $20 \%$ (Vogt et al., 1986). Therefore, fine roots are an important "currency" in forest primary production (Hendrick and Pregitzer, 1993; Gill and Jackson, 2000), and the key to the study of biomass in the forest ecosystem.

The current study analyzed the biomass of different layers in mixed stands with Masson pine comprising $<20 \%, 20$ to $40 \%, 40$ to $60 \%, 60$ to $80 \%$, and $>80 \%$ of this pine species present. The purpose of this study was to identify the optimal proportion of Masson pine in mixed stands in which maximal biomass can be obtained. This information is necessary for the establishment of commercial management of Masson pine carbon currency stands. 


\section{MATERIAL AND METHODS}

\section{Study area}

Study sites were located on the southeast edge of Dabieshan Mountain $\left(31^{\circ} 01^{\prime}\right.$ to $31^{\circ} 38^{\prime} \mathrm{N}, 117^{\circ} 05^{\prime}$ to $117^{\circ} 43^{\prime} \mathrm{W}$ ), close to Zong Yang County, Anhui Province, China. The area has a subtropical wet monsoon climate with four distinct seasons. The mean annual temperature is $16.5^{\circ} \mathrm{C}$, the mean annual sunshine is $2064.9 \mathrm{~h}$, and the mean annual precipitation is $1326.5 \mathrm{~mm}$. The rock base is mainly granite gneiss, and the soil is granite yellow brown soil, with a $\mathrm{pH}$ of 5.5 to 6.5 . The barren soil has a weak capacity to hold water. In order to ensure that tree species diversity is the only factor influencing productivity, stands were identified that were similar in growth and ecological factors but different in their proportion of Masson pine (Pinus massoniana). The general information of the plots is shown in Table 1 . The vegetation was a mix of middle subtropical to northern tropical deciduous to coniferous forests, composed mainly of pure Masson pine, scattered with broadleaf Phyllostachys bamboo. There were a few tree species, the most commonly identified as Euscaphis japonica, Vitex negundo, Dalbergia hupeana, Lindera glauca, and Pistacia chinensis. Less frequently identified were Liquidambar formosana, Platycarya strobilacea, Quercus acutissima, Smilax china, and Mallotus tenuifolius. The stands selected had been planted, were not irrigated, and had not been disturbed for more than 30 years. Broadleaf species invasion occurred naturally.

\begin{tabular}{|c|c|c|c|c|c|c|c|c|c|c|c|}
\hline \multirow[t]{2}{*}{$\begin{array}{l}\text { Sample } \\
\text { code }\end{array}$} & \multirow[t]{2}{*}{$\begin{array}{c}\text { Mixed } \\
\text { ratio }(\%)^{*}\end{array}$} & \multirow[t]{2}{*}{$\begin{array}{l}\text { Altitude } \\
\text { (m) }\end{array}$} & \multirow[t]{2}{*}{ Slope } & \multirow[t]{2}{*}{$\begin{array}{c}\text { Inclination } \\
\left({ }^{\circ}\right)\end{array}$} & \multirow[t]{2}{*}{$\begin{array}{l}\text { Slope } \\
\text { position }\end{array}$} & \multicolumn{2}{|c|}{$\begin{array}{l}\text { Density } \\
\text { (tree/ha) }\end{array}$} & \multicolumn{2}{|c|}{$\begin{array}{l}\text { Mean height } \\
\text { (m) }\end{array}$} & \multicolumn{2}{|c|}{$\begin{array}{c}\text { Mean trunk } \\
\text { diameter }(\mathrm{cm})\end{array}$} \\
\hline & & & & & & $\begin{array}{c}\text { Pinus } \\
\text { massoniana }\end{array}$ & $\begin{array}{l}\text { Broad-leaved } \\
\text { tree }\end{array}$ & $\begin{array}{c}\text { Pinus } \\
\text { massoniana }\end{array}$ & $\begin{array}{l}\text { Broad-leaved } \\
\text { tree }\end{array}$ & $\begin{array}{c}\text { Pinus } \\
\text { massoniana }\end{array}$ & $\begin{array}{c}\text { Broad-leaved } \\
\text { tree }\end{array}$ \\
\hline 1 & $<20$ & 163 & South & 23 & Upside & 150 & 450 & 8.3 & 7.6 & 15.9 & 15.2 \\
\hline 2 & $<20$ & 70 & South & 10 & Middle & 75 & 775 & 7.0 & 7.3 & 17.5 & 15.1 \\
\hline 3 & $<20$ & 161 & East & 18 & Underside & 175 & 700 & 5.9 & 7.7 & 11.9 & 16.4 \\
\hline 4 & $20-40$ & 62 & Northwest & 23 & Middle & 450 & 550 & 8.3 & 8.3 & 13.4 & 16.5 \\
\hline 5 & $20-40$ & 90 & West & 29 & Underside & 375 & 775 & 9.0 & 7.5 & 14.1 & 14.0 \\
\hline 6 & $20-40$ & 162 & South & 11 & Middle & 225 & 575 & 8.6 & 7.1 & 17.4 & 14.7 \\
\hline 7 & $40-60$ & 217 & South & 27 & Upside & 275 & 175 & 8.7 & 8.3 & 15.7 & 17.8 \\
\hline 8 & $40-60$ & 102 & South & 24 & Middle & 200 & 500 & 9.3 & 9.1 & 19.7 & 15.5 \\
\hline 9 & $40-60$ & 170 & South & 21 & Upside & 425 & 400 & 8.5 & 7.3 & 16.3 & 16.0 \\
\hline 10 & $60-80$ & 96 & East & 18 & Underside & 625 & 325 & 8.0 & 6.9 & 14.4 & 11.4 \\
\hline 11 & $60-80$ & 68 & Southwest & 20 & Underside & 600 & 350 & 9.8 & 7.1 & 13.9 & 12.7 \\
\hline 12 & $60-80$ & 156 & Southeast & 15 & Middle & 950 & 150 & 6.6 & 7.0 & 11.7 & 16.7 \\
\hline 13 & $>80$ & 217 & Southwest & 21 & Upside & 700 & 125 & 9.1 & 5.8 & 15.6 & 13.8 \\
\hline 14 & $>80$ & 157 & South & 26 & Middle & 1425 & 100 & 8.7 & 5.7 & 13.9 & 10.4 \\
\hline 15 & $>80$ & 80 & South & 20 & Underside & 1175 & 50 & 7.1 & 7.3 & 13.2 & 16.0 \\
\hline
\end{tabular}

*The actual percentages of Masson pine were 17.2, 35.6, 45.6, 75.2, 92.3\% in these stands.

\section{Sampling design}

Fifteen plots, situated away from the forest edge, with five different proportions of Masson pine in a mixed forest, were selected for analyzing the proportions of different species in the mixed woods effect on production of biomass. Except for the mixed proportions, the woodland habitat factors of these plots (including altitude, aspect, slope, slope position, soil properties, light, heat, and moisture) were basically the same, as was the stand age. Values of 
the mixed proportions of Masson pine in the 15 forest plots were measured based on surveys of three $20 \times 20 \mathrm{~m}$ standard areas of each plot, and were then classified into five levels, namely, $<20 \%, 20$ to $40 \%, 40$ to $60 \%, 60$ to $80 \%$, and $>80 \%$, which were marked as I, II, III, IV, and $\mathrm{V}$, respectively, for convenience. The actual average value of proportions of Masson pine for each level was $17.2,35.6,45.6,75.2$, and $92.3 \%$, respectively.

\section{Data collection}

From the end of July to early August 2009, in each selected mixed stand, one 0.04 ha circular sample plot was established for investigating biomass, understory vegetation, and understory plant diversity. To estimate the biomass in each sample plot, the following features were measured and examined in each plot.

\section{Above-ground arboreal biomass}

The diameter at breast height (DBH) and the height of the individual tree, in three $20 \mathrm{x}$ $20 \mathrm{~m}$ standard areas of each plot, were measured. A standard tree of each plot was then chosen, based on information collected from the average value of DBH and tree height of the whole plot. Three standard trees were cut down and divided into sections of $1 \mathrm{~m}$ and weighed fresh to obtain weights of the trunk, limbs, branches, leaves, and bark, separately. In a laboratory, samples were dried at a temperature of $70^{\circ} \mathrm{C}$ to a constant mass to determine the oven-dried biomass and were then weighed to the nearest $0.01 \mathrm{~g}$. The water content and dry weight were calculated accordingly. Finally, the biomass was calculated using the average sample tree method.

\section{Above-ground biomass of understory vegetation}

In each sample plot, five $2 \times 2 \mathrm{~m}$ subplots were randomly allocated to determine the understory vegetation biomass. The above-ground biomass of all shrubs and herbs was clipped from each of the five randomly located $4-\mathrm{m}^{2}$ subplots. The understory vegetation within the plots was investigated. The shrubs were separated from the herbs, and each group was weighed fresh. These samples were then oven-dried at $70^{\circ} \mathrm{C}$ to a constant mass to determine the oven-dried biomass, weighed to the nearest $0.01 \mathrm{~g}$.

$$
\mathrm{Wu}=\sum \mathrm{Wui} /(\mathrm{A} \times \mathrm{N}) \times 10,000
$$

where $\mathrm{Wu}$ is the biomass per hectare, $\sum \mathrm{Wui}$ is the cumulative sum of the biomass, $\mathrm{A}$ is the area of sample plots, and $\mathrm{N}$ is the number of sample plots.

\section{Fine root biomass}

From March 2008 to September 2009, in each sample area, 20 points were randomly selected along a zigzag. At each point, soil samples were collected from three layers $(0$ to 10 , 10 to 20 , and 20 to $30 \mathrm{~cm}$ ) using a soil drill of $6.8 \mathrm{~mm}$ inner diameter. A total of 270 samples were collected from 15 sample stands. The soil samples were numbered, put into plastic bags, and taken to a laboratory. There, they were soaked in water, and then washed under flowing 
water over a $0.5-\mathrm{mm}$ diameter soil screen. The cleaned roots were stored in bags and dried at $70^{\circ} \mathrm{C}$ for testing. The fine roots $(<2 \mathrm{~mm}$ in diameter $)$ were sorted.

\section{Statistical analysis}

To observe the relationships in biomasses across stand development, the field data for the above-ground tree, understory, and fine root, biomass, and total biomass of the mixed forest were calculated for each sample site by summing the samples for that site. The mean biomass was calculated for each of the mixed forest biomasses for each developmental stage, allowing observation of how the biomass varied for each stand. The $t$-test was used to test the fine root biomass. We used the following model to represent the understory vegetation biomass:

$$
\mathrm{Wu}=\sum \mathrm{Wui} /(\mathrm{A} \times \mathrm{N}) \times 10^{4}
$$

where $W u$ is the biomass per hectare, $\sum W u i$ is the cumulative sum of the biomass, $A$ is the area of quadrates, and $N$ is the number of quadrates.

The fine root standing biomass estimates were calculated as follows:

$$
\mathrm{R}\left(\mathrm{t} \cdot \mathrm{hm}^{-2}\right)=\text { Average weight of soil core fine root } \mathrm{x} 10^{2} /\left[\pi \cdot(\mathrm{D} / 2)^{2}\right]
$$

where $R$ is the fine root reserves, $A$ is the average weight of soil core fine root, and $D$ is the diameter of the soil drill.

\section{RESULTS}

\section{Above-ground tree biomass}

The above-ground tree biomass constitutes the largest portion of total biomass in these stands. Among the stands, when the proportion of Masson pine gradually increased from $<20$ to $>80 \%$, the above-ground biomasses displayed an increase-decrease trend, as shown in Table 2 . The order of the above-ground biomasses was III $>$ II $>$ IV $>$ V $>$ I. The difference between stands III and I was significant $(\mathrm{P}<0.01)$. The above-ground arboreal biomass in stand III was $281 \mathrm{Mg} / \mathrm{ha}$, whereas it was $217 \mathrm{Mg} /$ ha in stand I.

Table 2. Total above-ground biomass in the Masson pine mixed forest.
\begin{tabular}{lccc}
\hline Mixed ratio (\%) & Tree layer biomass (t/ha) & Understory biomass ( $\mathrm{t} / \mathrm{ha})$ & Above-ground biomass ( $\mathrm{t} / \mathrm{ha})$ \\
\hline $0-20 \%$ & 216.663 & 1.39 & 218.053 \\
$21-40 \%$ & 273.946 & 1.47 & 275.416 \\
$41-60 \%$ & 281.583 & 1.52 & 283.103 \\
$61-80 \%$ & 246.485 & 1.19 & 247.675 \\
$81-100 \%$ & 232.657 & 1.13 & 233.787 \\
\hline
\end{tabular}

\section{Understory biomasses}

The understory biomasses differed with changes in the proportion of Masson pine (Table 2). The order of the shrub biomasses was III $>$ II $>$ I $>$ V $>$ IV. Among these, the difference be- 
tween stands III and IV was significant $\left(0.38 \mathrm{t} / \mathrm{hm}^{2}, \mathrm{P}<0.01\right)$, and with the lowest being $0.98 \mathrm{t} /$ $\mathrm{hm}^{2}$ and the highest being $1.36 \mathrm{t} / \mathrm{hm}^{2}$. The order of biomasses of the herb layer was IV $>$ III $>$ II $>$ $\mathrm{V}>\mathrm{I}$. Among these, the herb biomasses were 0.21 and $0.07 \mathrm{t} / \mathrm{hm}^{2}$, respectively, in stands IV and I. The former was 3 times more than the latter. The difference between these two proportions was significant $(\mathrm{P}<0.01)$. Stand III had the largest arboreal biomass but not the largest herb biomass. Stand I had the lowest herb biomass but relatively large arboreal biomass. These results indicate that trees influence the availability of light to herbs, influencing the development of the herb layer.

\section{Above-ground total biomass}

The above-ground total biomasses increased in the order of stand types III $>$ II $>$ IV $>\mathrm{V}>\mathrm{I}$ (Table 2). The difference between stands III and I was significant $\left(65.05 \mathrm{t} / \mathrm{hm}^{2}, \mathrm{P}<\right.$ 0.01 ), with their above-ground total biomasses being 283.103 and $218.053 \mathrm{t} / \mathrm{hm}^{2}$, respectively. The tree biomass is the major layer of those above ground. The differences in the understory biomasses between the different stands were small. The arboreal and understory biomasses in stand III were the largest. Therefore, the above-ground biomass of stand III was also the largest.

\section{Fine root biomasses}

Fine root biomasses displayed a declining trend as the depth of soil increased (Figure 1). Most of the fine root biomass was within the 0 to $10 \mathrm{~cm}$ layer. Within the $30 \mathrm{~cm}$ depth, the highest fine root biomass was found in the top $10 \mathrm{~cm}$ of soil, being $49.4 \%$. In stand III, soil strata 0 to 10 and 10 to $20 \mathrm{~cm}$ had the largest fine root biomass. In stand II, the 20 to $30 \mathrm{~cm}$ soil stratum had the largest fine root biomass. The difference between stands III and II was significant $(\mathrm{P}<0.01)$. Stand comparison revealed that the fine root biomass was the largest in stand III, reaching $1.799 \mathrm{t} / \mathrm{hm}^{2}$, whereas it was the least in stand II, being only $1.581 \mathrm{t} / \mathrm{hm}^{2}$. The order of fine root biomasses was III $>$ I $>$ IV $>$ V $>$ II. In each stand type, the fine root biomass in the 0 to $10 \mathrm{~cm}$ soil stratum was significantly different from that in the other two strata. In stand III, the fine root biomasses within the 10 to $20 \mathrm{~cm}$ soil stratum had a significant difference. The fine root biomasses in stand II within the 20 to $30 \mathrm{~cm}$ soil layer were significantly different. The total fine root biomasses were significantly different between stands III and II.

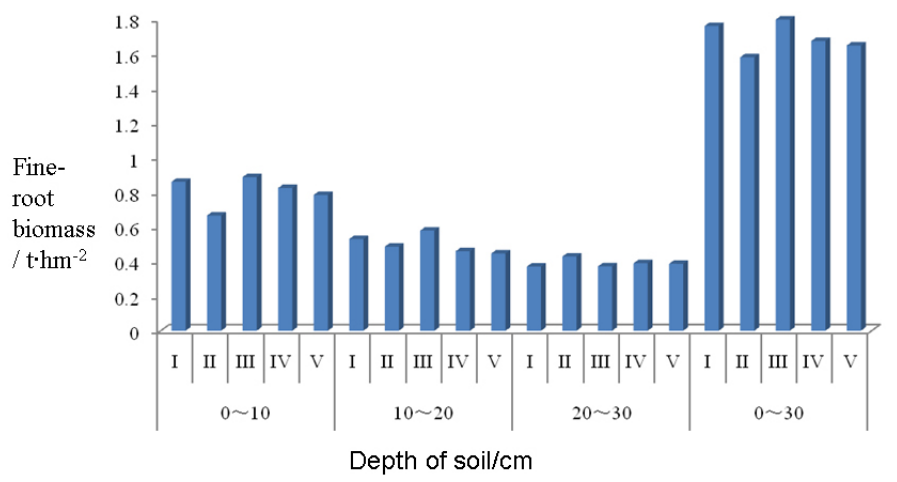

Figure 1. Fine-root biomass distribution in $0-30-\mathrm{cm}$ soil layer of mixed forest (I, II, III, IV, and V stands for 5 different mixed ratios of Masson pine in sampling plots). 
The $t$-testing of the independent samples revealed that stand III, in comparison with stands I, II, III, and V, had significant differences within the 0 to $10 \mathrm{~cm}$ layer (Table 3 ). In stand III, the results of the $t$-test showed a significant difference from the other stands, within the 10 to $20 \mathrm{~cm}$ layer (Table 4). In the 20 to $30 \mathrm{~cm}$ layer, stand III also had significant differences in comparison with stands I, II, III, and V, (Table 5).

\begin{tabular}{|c|c|c|c|c|}
\hline & $0-20 \%$ & $21-40 \%$ & $41-60 \%$ & $61-80 \%$ \\
\hline \multicolumn{5}{|l|}{$0-20 \%$} \\
\hline $21-40 \%$ & $-1.507(0.150)$ & & & \\
\hline $41-60 \%$ & $2.334(0.032)$ & $3.498(0.003)$ & & \\
\hline $61-80 \%$ & $-3.740(0.002)$ & $-3.273(0.004)$ & $4.108(0.001)$ & \\
\hline $81-100 \%$ & $-1.403(0.179)$ & $-2.057(0.050)$ & $3.462(0.003)$ & $3.345(0.004)$ \\
\hline
\end{tabular}

Numbers in parentheses indicate the $\mathrm{P}$ value.

\begin{tabular}{|c|c|c|c|c|}
\hline & $0-20 \%$ & $21-40 \%$ & $41-60 \%$ & $61-80 \%$ \\
\hline \multicolumn{5}{|l|}{$0-20 \%$} \\
\hline $21-40 \%$ & $-0.102(0.920)$ & & & \\
\hline $41-60 \%$ & $1.261(0.224)$ & $2.119(0.049)$ & & \\
\hline $61-80 \%$ & $-2.779(0.013)$ & $-2.878(0.010)$ & $2.456(0.025)$ & \\
\hline $81-100 \%$ & $0.058(0.954)$ & $0.230(0.821)$ & $2.252(0.038)$ & $3.345(0.004)$ \\
\hline
\end{tabular}

Numbers in parentheses indicate the $\mathrm{P}$ value.

Table 5. Fine-root biomass paired-samples $t$-test in 20-30-cm soil layer of mixed forest.

\begin{tabular}{|c|c|c|c|c|}
\hline & $0-20 \%$ & $21-40 \%$ & $41-60 \%$ & $61-80 \%$ \\
\hline \multicolumn{5}{|l|}{$0-20 \%$} \\
\hline $21-40 \%$ & $-0.610(0.551)$ & & & \\
\hline $41-60 \%$ & $0.939(0.361)$ & $3.115(0.006)$ & & \\
\hline $61-80 \%$ & $0.442(0.678)$ & $0.332(0.774)$ & $2.267(0.037)$ & \\
\hline $81-100 \%$ & $-0.551(0.589)$ & $-0.159(0.876)$ & $2.509(0.023)$ & $-0.421(0.037)$ \\
\hline
\end{tabular}

Numbers in parentheses indicate the $\mathrm{P}$ value.

\section{DISCUSSION}

Among the five Masson pine stands, the order of above-ground arboreal biomasses was (by proportion) III $>$ II $>$ IV $>$ V $>$ I. Among these, the above-ground arboreal biomass in stands with $45.6 \%$ Masson pine was the largest, whereas that in stands with $92.3 \%$ Masson pine was the smallest. The understory biomass was largely composed of the shrub layer. Although herbs occupied much of the surface area and were abundant, their biomass was the smallest portion. As the proportion of ground surface area of Masson pine increased, the understory biomass first increased and then decreased (the maximal shrub biomass was $1.36 \mathrm{t} / \mathrm{hm}^{2}$ measured in stands with $45.6 \%$ Masson pine). The fine roots of Masson pine and broadleaf trees were mainly found in the 0 to $10 \mathrm{~cm}$ soil layer. The deeper the soil was, the fewer fine roots were found. The largest fine root biomass was measured in stands with $45.6 \%$ Masson pine, whereas the lowest fine root biomass was identified in stands with $35.6 \%$ Masson pine. The differences between the two stands were significant.

Stands with $45.6 \%$ Masson pine had the largest above-ground tree, understory, and fine root biomasses. This proportion of Masson pine in the stand positively influences the growth of stands and is an important factor influencing biomass creation. 


\title{
ACKNOWLEDGMENTS
}

\author{
Research supported by the State Forestry Administration, P.R. China (Project \\ \#201004016).
}

\section{REFERENCES}

Arthur MA and Fahey TJ (1992). Biomass and nutrients in an Engelmann spruce - subalpine fir forest in north central Colorado: pools, annual production, and internal cycling. Can. J. For. Res. 22: 315-325.

Cardinale BJ, Wright JP, Cadotte MW, Carroll IT, et al. (2007). Impacts of plant diversity on biomass production increase through time because of species complementarity. Proc. Natl. Acad. Sci. U. S. A. 104: 18123-18128.

Fogel R and Hunt G (1979). Fungal and arboreal biomass in a western Oregon Douglas-fir ecosystem: distribution patterns and turnover. Can. J. For. Res. 9: 245-256.

Gill RA and Jackson RB (2000). Global patterns of root turnover for terrestrial ecosystems. New Phytol. 147: 13-31.

Grier CC, Vogt KA, Keyes MR and Edmonds RL (1981). Biomass distribution and above- and below-ground production in young and mature Abies amabilis zone ecosystems of the Washington Cascades. Can. J. For. Res. 11: 155-167.

Hendrick RL and Pregitzer KS (1993). The dynamics of fine root length, biomass, and nitrogen content in two northern hardwood ecosystems. Can. J. For. Res. 23: 2507-2520.

Hooper DU, Chapin FS, Ewel JJ, Hector A, et al. (2005). Effects of biodiversity on ecosystem functioning: a consensus of current knowledge. Ecol. Monogr. 75: 3-35.

Isbell FI, Polley HW and Wilsey BJ (2009). Biodiversity, productivity and the temporal stability of productivity: patterns and processes. Ecol. Lett. 12: 443-451.

Jackson RB, Mooney HA and Schulze ED (1997). A global budget for fine root biomass, surface area, and nutrient contents. Proc. Natl. Acad. Sci. U. S. A. 94: 7362-7366.

Loreau M and Hector A (2001). Partitioning selection and complementarity in biodiversity experiments. Nature 412: 72-76.

Loreau M, Naeem S, Inchausti P, Bengtsson J, et al. (2001). Biodiversity and ecosystem functioning: current knowledge and future challenges. Science 294: 804-808.

Marquard E, Weigelt A, Temperton VM, Roscher C, et al. (2009). Plant species richness and functional composition drive overyielding in a six-year grassland experiment. Ecology 90: 3290-3302.

Pande PK (2005). Biomass and productivity in some disturbed tropical dry deciduous teak forests of Satpura plateau, Madhya Pradesh. Trop. Ecol. 46: 229-239.

Pregitzer KS, Hendrick RL and Fogel R (1993). The demography of fine roots in response to patches of water and nitrogen. New Phytologist 125: 575-580.

Spehn EM, Hector A, Joshi J, Scherer-Lorenzen M, et al. (2005). Ecosystem effects of biodiversity manipulations in European grasslands. Ecol. Monogr. 75: 37-63.

Tilman D, Wedin D and Knops J (1996). Productivity and sustainability influenced by biodiversity in grassland ecosystems. Nature 379: 718-720.

Tilman D (1999). The ecological consequences of changes in biodiversity: a search for general principles. Ecology 80: 1455-1474.

Usman S, Singh SP, Rawat YS and Bargali SS (2000). Fine root decomposition and nitrogen mineralisation patterns in Quercus leucotrichophora and Pinus roxburghii forests in central Himalaya. For. Ecol. Manage. 131: 191-199.

Vogt KA, Grier CC, Gower ST, Douglas GS, et al. (1986). Overestimation of net root production: A real or imaginary problem. Ecology 67: 577-579. 